University of Nebraska - Lincoln

DigitalCommons@University of Nebraska - Lincoln

Combining power plant water needs and carbon dioxide storage using saline formations: Implications for carbon dioxide and water management policies

\author{
Peter Kobos \\ Sandia National Laboratories, Albuquerque, NM \\ Malynda Cappelle \\ University of Texas at El Paso, El Paso, TX \\ Jim Krumhansl \\ Sandia National Laboratories, Albuquerque, NM \\ Thomas Dewers \\ Sandia National Laboratories, Albuquerque, NM \\ Andrea McNemar \\ National Energy Technology Laboratory,Morgantown, WV \\ See next page for additional authors
}

Follow this and additional works at: https://digitalcommons.unl.edu/usdoepub

Part of the Bioresource and Agricultural Engineering Commons

Kobos, Peter; Cappelle, Malynda; Krumhansl, Jim; Dewers, Thomas; McNemar, Andrea; and Borns, David, "Combining power plant water needs and carbon dioxide storage using saline formations: Implications for carbon dioxide and water management policies" (2011). US Department of Energy Publications. 118.

https://digitalcommons.unl.edu/usdoepub/118

This Article is brought to you for free and open access by the U.S. Department of Energy at DigitalCommons@University of Nebraska - Lincoln. It has been accepted for inclusion in US Department of Energy Publications by an authorized administrator of DigitalCommons@University of Nebraska - Lincoln. 


\section{Authors}

Peter Kobos, Malynda Cappelle, Jim Krumhansl, Thomas Dewers, Andrea McNemar, and David Borns 


\title{
Combining power plant water needs and carbon dioxide storage using saline formations: Implications for carbon dioxide and water management policies
}

\author{
Peter H. Kobos ${ }^{\mathrm{a}, *}$, Malynda A. Cappelle ${ }^{\mathrm{b}}$, Jim L. Krumhansl ${ }^{\mathrm{c}}$, Thomas A. Dewers ${ }^{\mathrm{d}}$, \\ Andrea McNemar ${ }^{\mathrm{e}}$, David J. Borns ${ }^{\mathrm{f}}$ \\ a Earth Systems Department, Sandia National Laboratories, P.O. Box 5800, MS 0749, Albuquerque, NM 87185, USA \\ ${ }^{\mathrm{b}}$ Center for Inland Desalination Systems, University of Texas at El Paso, 500 West University Avenue, El Paso, TX 79968, USA \\ c Geochemistry Department, Sandia National Laboratories, P.O. Box 5800, MS 0754, Albuquerque, NM 87185, USA \\ d Geomechanics Department, Sandia National Laboratories, P.O. Box 5800, MS 0751, Albuquerque, NM 87185, USA \\ e National Energy Technology Laboratory, 3610 Collins Ferry Road, P.O. Box 880, MS P03D, Morgantown, WV 26507-0880, USA \\ ${ }^{\mathrm{f}}$ Geotechnology and Engineering Department, Sandia National Laboratories, P.O. Box 5800, MS0706, Albuquerque, NM 87185, USA
}

\section{A R T I C L E I N F O}

\section{Article history:}

Received 12 October 2010

Received in revised form 22 February 2011

Accepted 14 March 2011

Available online 2 May 2011

\section{Keywords:}

Carbon dioxide storage

Water treatment costs

Saline formation assessment

Power generating station cooling water

\begin{abstract}
A B S T R A C T
Research involving management of carbon dioxide has increased markedly over the last decade as it relates to concerns over climate change. Capturing and storing carbon dioxide $\left(\mathrm{CO}_{2}\right)$ in geological formations is one of many proposed methods to manage, and likely reduce, $\mathrm{CO}_{2}$ emissions from burning fossil fuels in the electricity sector. Saline formations represent a vast storage resource, and the waters they contain could be managed for beneficial use. To address this issue, a methodology was developed to test the feasibility of linking coal-fired power plants, deep saline formations for $\mathrm{CO}_{2}$ storage, and extracting and treating saline waters for use as power plant cooling water.

An illustrative hypothetical case study examines a representative power plant and saline formation in the south-western United States. A regional assessment methodology includes analysis of injectioninduced changes in subsurface groundwater chemistry and fate and transport of supercritical $\mathrm{CO}_{2}$. Initial water- $\mathrm{CO}_{2}$-formation reactions include dissolution of carbonate minerals as expected, and suggest that very little $\mathrm{CO}_{2}$ will be stored in mineral form within the first few centuries. Reservoir simulations provide direct input into a systems-level economic model, and demonstrate how water extraction can help manage injection-induced overpressure. Options for treatment of extracted water vary depending upon site specific chemistry. A high efficiency reverse osmosis system $\left(\mathrm{HERO}^{\mathrm{TM}}\right)$ shows promise for economical desalination at the volumes of recovered water under consideration. Results indicate a coupled use $\mathrm{CO}_{2}$ storage and water extraction and treatment system may be feasible for tens to hundreds of years.
\end{abstract}

(c) 2011 Elsevier Ltd. All rights reserved.

\section{Introduction}

In some regions of the United States, saline water-bearing formations have the potential to provide alternative sources to supplement growing water needs for all types of uses. At the same time, saline formations have captured the attention of $\mathrm{CO}_{2}$ storage researchers, including those who developed the National Carbon Sequestration Database and Geographic Information System (NatCarb, 2008). A better understanding is needed of saline water resources when considering saline formations for both purposes. Injecting $\mathrm{CO}_{2}$ into a saline formation may pressurize the

\footnotetext{
* Corresponding author. Tel.: +1 505845 7086; fax: +1 5058440240.

E-mail addresses: phkobos@sandia.gov(P.H. Kobos), macappelle@utep.edu(M.A. Cappelle),jlkrumh@sandia.gov(J.L. Krumhansl),tdewers@sandia.gov (T.A. Dewers), Andrea.McNemar@netl.doe.gov (A.McNemar),djborns@sandia.gov (D.J. Borns).
}

saline formation and potentially alter formation properties and/or induce leakage if not properly managed. Coupling the pumping of saline waters, and so relieving overpressure, could become a potential solution, while at the same time providing a valuable resource if this water could be treated and made available for use in a power generating station (plant) for cooling purposes.

In this study, three linked areas of analysis address this multidisciplinary issue; a geotechnical assessment (subsurface geochemical and spatio-temporal reservoir modeling), a suite of water treatment options, and a systems-level analysis bring together physical and economic considerations throughout the geo- and power plant-system. One geotechnical question is whether injected $\mathrm{CO}_{2}$ modifies groundwater chemistry to the point of influencing the economic viability of water treatment options. A critical issue is to ensure $\mathrm{CO}_{2}$ will not be released once stored underground. A second issue to be examined is how the $\mathrm{CO}_{2}$ storage system may be managed to minimize potential deleterious effects on the saline 


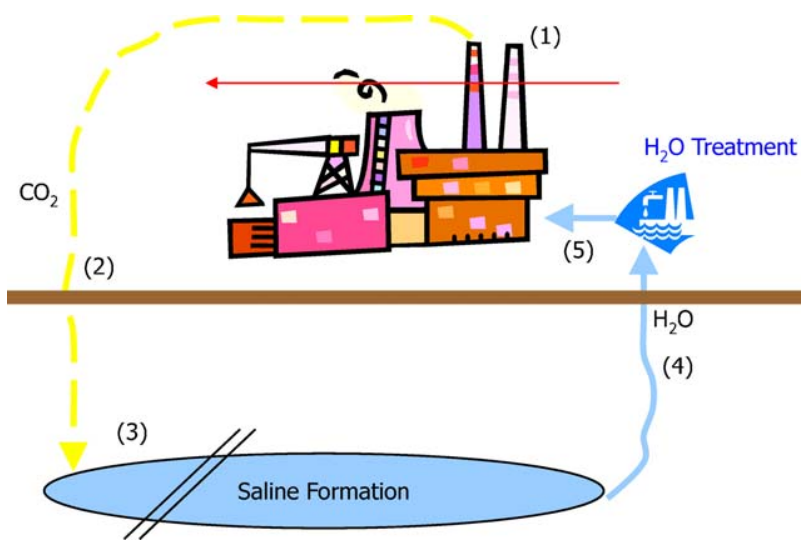

Fig. 1. The assessment methodology and model framework. (1) Power plant metrics, (2) $\mathrm{CO}_{2}$ capture and storage system, (3) saline formation geotechnical modeling assessment, (4) water extraction analysis, (5) water treatment analysis for power plant cooling.

formation itself. The potential deleterious effects of injecting $\mathrm{CO}_{2}$ into the saline formation may include a decrease in $\mathrm{pH}$, a resultant increase in metal concentrations, and increased salinity due to the reaction of $\mathrm{CO}_{2}$ with the saline formation minerals (Kharaka et al., 2006, 2009). Additionally, several water treatment and desalination issues need to be addressed as they relate to the quality of the treatment concentrate and disposal options. Each of these three areas of interest must be adequately addressed and integrated to determine the relative cost-effectiveness of using treated saline waters in power plant systems. Fig. 1 illustrates the overarching conceptual analytical framework for the analysis.

\section{Methods}

The analysis builds from the framework outlined in Fig. 1 by first selecting potential geological saline formations in the region that appear to meet a defined coupled-use criteria. The geochemical impact of $\mathrm{CO}_{2}$ injection is determined from geochemical modeling using REACT (Bethke, 1998) coupled with knowledge of in situ pore water chemistry and formation mineralogy. Reservoir modeling using TOUGH2 (Pruess et al., 1999) investigates how a subsurface $\mathrm{CO}_{2}$ plume may evolve over time, while additional analysis assesses the engineering and other resources required to develop a water extraction and treatment system. Finally, the analysis applies a working analytical economic-engineering systems approach to bring together and evaluate all of these components in a single integrated assessment model.

To address the multidisciplinary aspects of the analysis, a decision framework was developed to calculate both initial performance and economic uncertainty. Fig. 2 illustrates the underlying framework used to develop the integrated assessment model and the subsequent components outlined in Fig. 1.

The results of the saline formation evaluation include the illustrative levelized cost of electricity (LCOE), formation longevity for $\mathrm{CO}_{2}$ capture and storage (CCS), extracted water (EW) budget, and additional system costs. The framework and subsequent integrated assessment are applied to a representative power plant based on the San Juan Generating Station (SJGS) and several saline formations within the San Juan Basin of northwestern New Mexico, United States.

This framework draws from the work of the larger $\mathrm{CO}_{2}$ storage research community's guidelines and recommendations when addressing site screening, selection and characterization. Bachu and Adams (2003), for example, developed a detailed methodology to calculate the ultimate $\mathrm{CO}_{2}$ storage capacity for saline formations. The United States Department of Energy (DOE) developed a national program to address regional considerations for $\mathrm{CO}_{2}$ storage. Amongst seven designated regional carbon dioxide storage partnership programs, substantial siting and characterization methodological work was completed in the first phase of the efforts to develop the first Carbon Sequestration Atlas outlining a common methodology for capacity assessment for saline formations, depleted oil and gas fields, and coal seams. Following these efforts, the validation and development phases developed a plan to implement small-scale field tests and larger-scale projects to implement the down-select performed in the characterization phase (Klara et al., 2003; Litynski et al., 2008, 2009).

Additionally, many site-specific and general cases to store $\mathrm{CO}_{2}$ in saline formations offer several lessons to build from regarding site selection, pressure management, and add to the growing body of literature as to the feasibility of storing $\mathrm{CO}_{2}$ in saline formations (Lucier and Zoback, 2008; Nicot, 2008; Grataloup et al., 2009; Michael et al., 2009; Medina et al., 2011; Hovorka et al., 2000; Herzog, 2010). To potentially help guide the growing number of studies and projects, the International Energy Agency developed an overarching review of the risk assessment and terminology practices within the $\mathrm{CO}_{2}$ storage community in an effort to help inform professionals working (or that may begin to work) in this applied field (IEAGHG, 2009).

\section{Geologic background}

For additional perspective regarding the San Juan Basin, Fig. 3 illustrates the region used throughout the decision framework and integrated assessment. The basin is a bowl-shaped structure formed in early Tertiary time (Paleocene to early Oligocene), during which it filled with several thousand feet of shallow marine and near shore deposits (the Fruitland coal-bearing formations and overlying Kirtland Formation, the latter being a potential barrier to the upward migration of $\mathrm{CO}_{2}$ that might be stored in the Fruitland). Allis et al. (2003) offers a good characterization of the region.

The last deposits laid down prior to formation of the San Juan Basin were a thick sequence of Cretaceous shallow marine shales which are interbedded with occasional sandy layers reflecting the positions of former beaches. These sand units have relatively high permeability in some regions. At the base of this sequence lies the Dakota sandstone, below which lies the Jurassic Morrison Formation. Beneath this are still more alternating layers of sandstones, conglomerates, shales and limestones, including the Permian Hermosa limestone. The whole stack of sediments ultimately rests on a basement of very low permeability 'crystalline' Precambrian rocks (granite, gneiss, schist, etc.).

The SJGS is located on the western edge of the basin (Fig. 3). East of this site, wells several thousand feet deep would barely penetrate the Tertiary basin fills or late Cretaceous strata, while west of the site a similar well could penetrate much further down, perhaps all the way into Permian Hermosa Formation limestone.

\section{Results}

\subsection{Evaluation criteria for saline formations}

Two evaluation criteria for the region and its potential for coupled-use $\mathrm{CO}_{2}$ storage and saline water utilization applications are proposed herein. First, saline formation water must be both available and treatable economically. Regulatory considerations for waters with less than 10,000 parts per million ( $\mathrm{ppm}$ ) of total dissolved solids (TDS) (e.g., 10,000 g of salt per 1,000,000 g of solution) dictate that these waters would likely not be considered for $\mathrm{CO}_{2}$ storage (EPA, 2008). Additionally, economic desalination of saline waters may prove challenging for waters with TDS beyond 


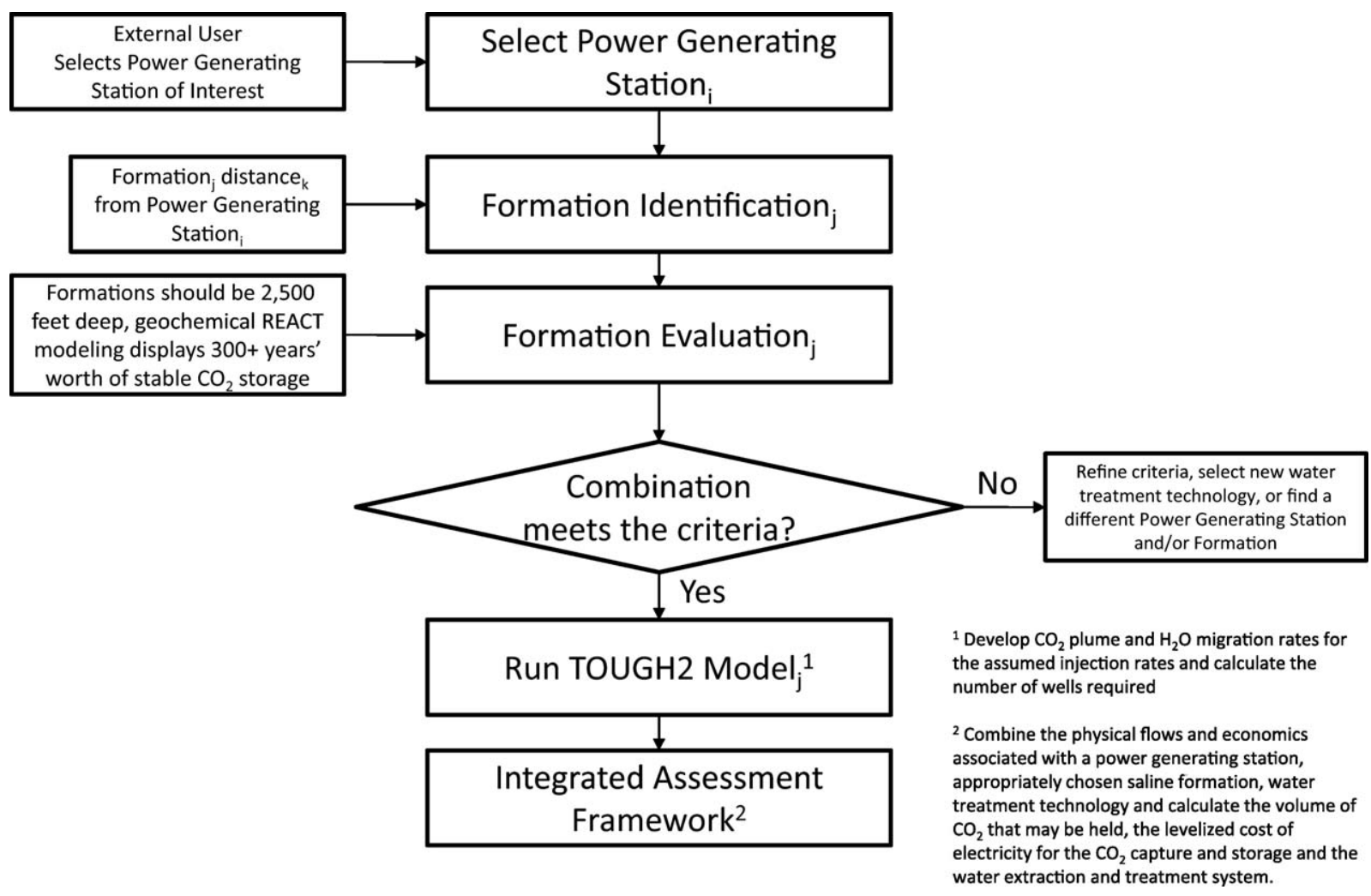

Fig. 2. The decision framework as applied to one representative power plant (i), and several geologic saline water-bearing formations (j).

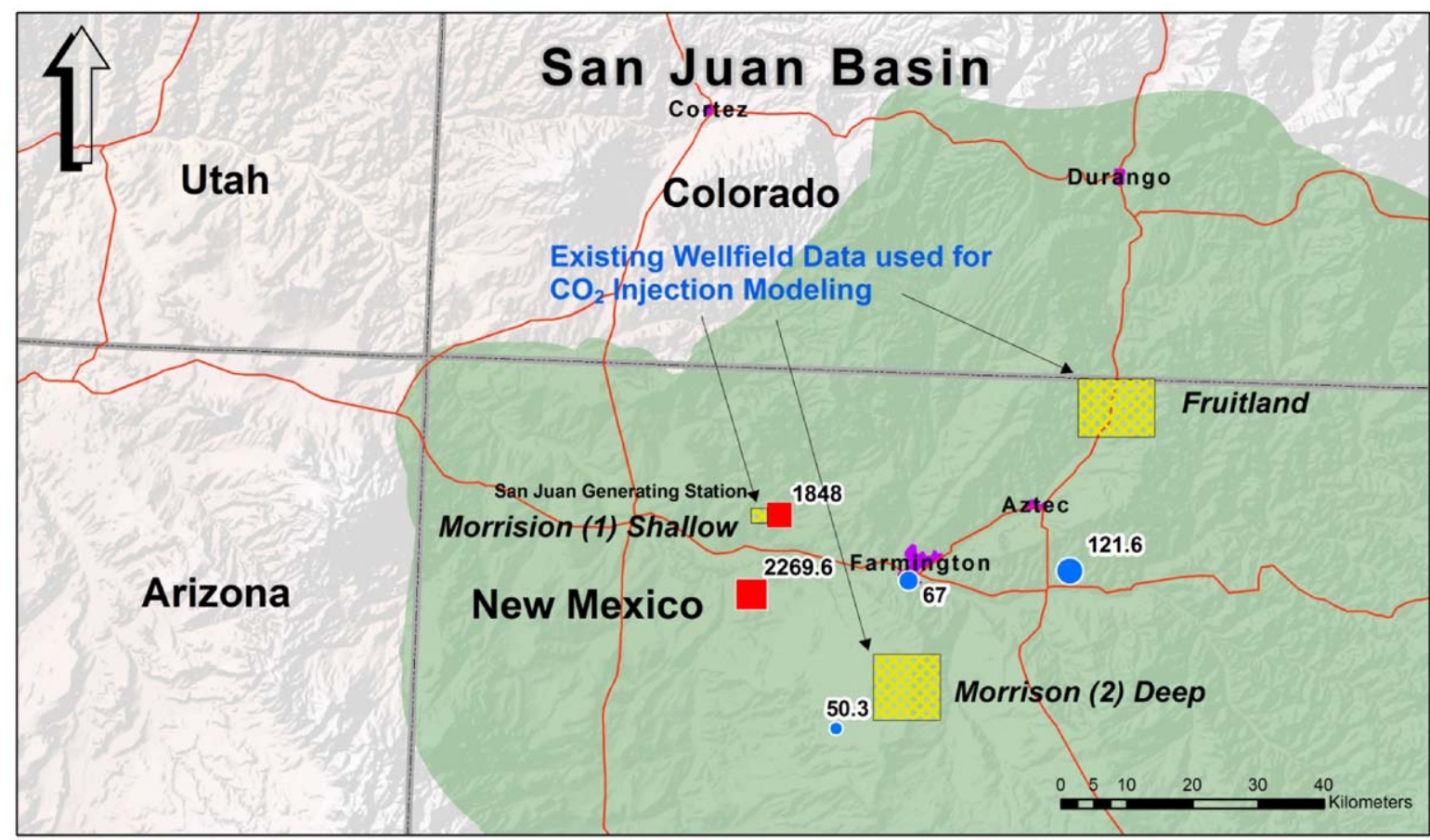

Natural Gas Power Plants nameplate capacity (MW)

- 50.3

- 67

121.6
Coal Power Plants nameplate capacity (MW)

1848

2269.6

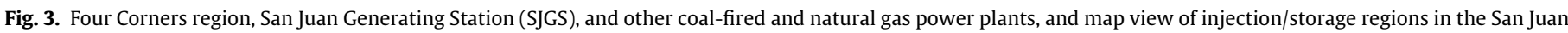
Basin, New Mexico, United States. 
$35,000 \mathrm{ppm}$ due to higher capital costs, larger amounts of energy required, and practical limits to fresh water recovery efficiency for the reverse osmosis systems. Thermal desalination methods could be utilized, but with generally higher costs and lower efficiencies (NRC, 2008; USBR and SNL, 2003). Second, the depth of a host formation into which $\mathrm{CO}_{2}$ is injected must be at least $2500 \mathrm{ft}$ in order to confine the gas at the requisite pressure and ideally, maintain the majority of the $\mathrm{CO}_{2}$ within the supercritical phase (i.e., a density of about $600 \mathrm{~kg} / \mathrm{m}^{3}$ ).

With these criteria in mind, the study builds from the NatCarb database (NatCarb, 2008) and analyzes wells within about $50-80 \mathrm{~km}$ (initially) of the target power plant that are both of sufficient depth, and have a record of producing waters with the desired salinity range with additional detail provided in Kobos et al. (2008, 2010). This radius of influence derives from economic and practical considerations of pumping $\mathrm{CO}_{2}$ between plant and injection site locations.

Based on storage, an initial formation assessment (e.g., Allis et al., 2003; NatCarb, 2008) has determined several suitable formations in the San Juan Basin region nearby the SJGS. These include the Cretaceous Fruitland, Point Lookout, Dakota and Gallup Sandstone in Mancos Formations, members of the Morrison Formation, and the Hermosa Group of the Paradox Formation. Other formations were rejected either because the water is too saline for economical treatment, or being too shallow for injection and storage of supercritical $\mathrm{CO}_{2}$.

The Hermosa/Paradox Formation was eliminated from the selection of formations due to the fact that it lies below the other formations so that, at least to the east of the SJGS, drilling a well to access this formation would hit all the other formations first. Also, because the formation actually consists of a limestone-shale mix it might be difficult to argue that it may contain a sufficient amount of saline water and/or $\mathrm{CO}_{2}$ storage capacity. The Gallup, Point Lookout and Dakota sandstone formation waters all have TDS levels less than $10,000 \mathrm{ppm}$, and so were also eliminated from consideration. The Fruitland sites have TDS levels between the acceptable range of 10,000 and 35,000 ppm TDS, but only one site is beyond $2500 \mathrm{ft}$ deep. Finally, the Morrison Formation has sufficient capacity, a wide regional extent, acceptable depth, and favorable geochemical properties. To assess feasibility of our coupled-use approach, we examine the Fruitland and Morrison Formations as examples.

\subsection{Geochemical modeling}

Our analysis evaluates whether injecting $\mathrm{CO}_{2}$ into these representative formations would initiate deleterious chemical changes such that undesirable constituents such as heavy metals may become sufficiently mobilized due to changes in $\mathrm{pH}$ and other notable interactive effects. To determine this, in situ water chemistry was obtained for the Fruitland and Morrison Formations. This background geochemical information was then used in investigating several scenarios of geochemical changes following injection of $\mathrm{CO}_{2}$. Relevant time frames for these scenarios range from approximately 100 years for activities related to current power plant operations out to 350 years.

The reaction path code REACT (Bethke, 1998) was used to assess what chemical changes might occur if $\mathrm{CO}_{2}$ was injected into various formations. Kobos et al. (2008) contains details on the modeling approach and its application to other sites. Briefly, the REACT models considered mixes of the appropriate formation minerals and brackish (saline) water together with an excess of $\mathrm{CO}_{2}$. Reaction rates for the minerals were typical values found in the literature $\mathrm{Xu}$ et al., 2003, 2004, 2005, 2007; Pruess et al., 2003; White et al., 2005), and the proportions of different minerals put into the models were based on formation descriptions in the geologic literature. Consideration was given to (1) how the fluid and rock would interact in the absence of $\mathrm{CO}_{2}$ (the result of which should compare favorably with the actual assemblage of minerals found in a formation that had equilibrated with that brackish water); (2) the interaction of the brackish water and $\mathrm{CO}_{2}$ in the absence of any rock (essentially a baseline for assessing how the brine chemistry changes when the brackish water- $\mathrm{CO}_{2}$ mix comes in contact with the rock); (3) the state of the system after 100 years; (4) the state of the system after 350 years; and (5) after the $\mathrm{CO}_{2}$-rock-brackish water mix had fully equilibrated (presumably many thousands of years into the future) Details of these calculations can be found in Kobos et al., 2008; here we focus only on the salient features of the geochemical modeling results.

The main geochemical considerations relative to using the waters extracted from the Morrison and Fruitland Formations are:

- Water users will (still) need to accommodate levels (parts per million) of both silica and iron, and possibly bisulfide (HS ${ }^{-}$).

- In time frames relevant to $\mathrm{CO}_{2}$ storage, the overall salinity levels of $\mathrm{CO}_{2}$-charged brackish water will not change much from that characteristic of the indigenous brines. However, levels of minor constituents such as magnesium, calcium, potassium, and sulfate may have changed.

- Clays and other Al-Si containing minerals only react very slowly with the mildly acidic $\mathrm{CO}_{2}$-charged brackish water. Hence, mineralization of the injected $\mathrm{CO}_{2}$ is not going to be a quantitatively significant process until many thousands of years have elapsed.

- Precipitation of calcium sulfate (as the mineral phases gypsum or anhydrite) could occur in the short term and possibly impact $\mathrm{CO}_{2}$ injection activities.

\subsection{Reservoir modeling of $\mathrm{CO}_{2}$ injection into San Juan Basin saline formations}

Carbon dioxide injection and storage in two saline formations in the San Juan Basin were assessed by combining information on formation and caprock geometry and properties with reservoir modeling using TOUGH2 (Pruess et al., 1999). Three sites were examined in detail based on the above criteria. These included the initial 'Morrison (1) Shallow' site, located within the Jurassic Morrison Formation (Dam et al., 1990a) about $1.4 \mathrm{~km}$ deep and $24 \mathrm{~km}$ north and west of Farmington, NM, USA; the 'Morrison (2) Deep' site, located approximately $1.9 \mathrm{~km}$ deep and $16 \mathrm{~km}$ south of Farmington, NM, USA; and a third site within the Fruitland Formation, a little less than $1 \mathrm{~km}$ deep and $24 \mathrm{~km}$ east of Farmington, NM, USA (Fig. 3). Simulations of injection of supercritical carbon dioxide were done using the TOUGH2 software (Pruess et al., 1999 ) with the $\mathrm{ECO} 2 \mathrm{~N}$ equation of state for $\mathrm{CO}_{2}$-brine-salt multiphase system (Pruess, 2005). In order to constrain saline formation geometries and flow properties, earth models of both sites were developed using information from the State of New Mexico Oil Conservation Division (OCD) online database (EMNRD, 2008) on petroleum wells in the region, combined with data on hydraulic conductivities from calibrated United States Geological Survey flow models and other recent results obtained from the National Energy Technology Laboratory's Southwest Regional Partnership on Carbon Sequestration.

\subsubsection{Geologic framework (earth) models}

A first step in the development of a numerical $\mathrm{CO}_{2}$ storage simulator for the SJGS is to create a geologic framework, or earth model, to represent the relevant rock strata in the subsurface. Using data from the OCD and data from the literature (e.g., Stone and Mizell, 1978), the analysis compiled petroleum well log data for the San Juan Basin sites. Formation boundary locations from well log data are combined in a three-dimensional earth model using C-Tech's MVSTM $^{\mathrm{TM}}$ software. Point data are 'kriged' to create boundary sur- 


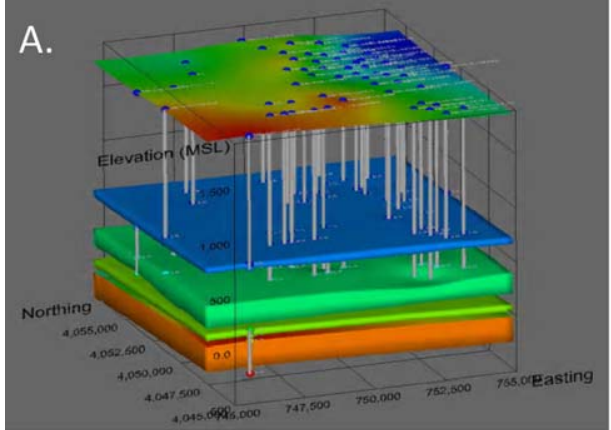

Point Lookout Formation

Gallup Formation

Dakota Formation

Morrison Formation

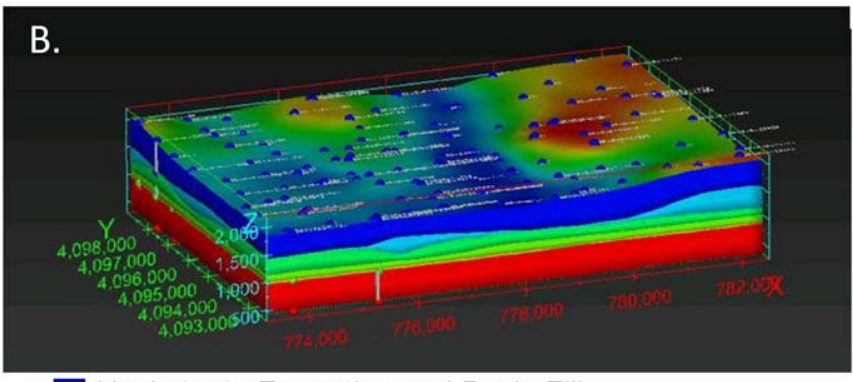

Nacimiento Formation and Basin Fill

Ojo Alamo Sandstone

Kirtland Formation (caprock seal)

Fruitland Formation (injection target)

Pictured Cliffs Sandstone

Lewis Formation (confining layer)

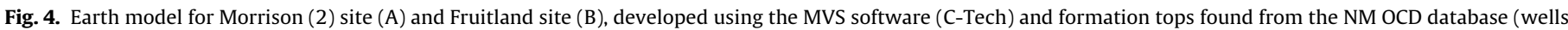

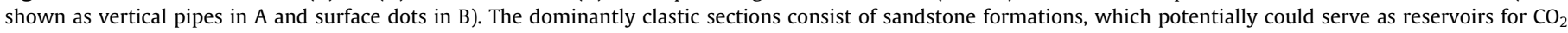

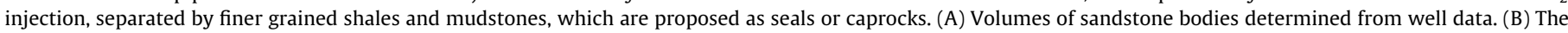

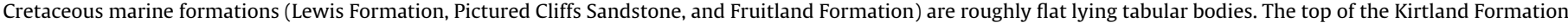
(dark green) is part of a regional unconformity, and shows large paleo-topography comparable to a modern river channel in the present day surface topography.

faces which constrain formation geometries. Fig. 4 portrays earth models for the Morrison (2) and Fruitland sites (the shallower Morrison (1) case is similar to the deeper Morrison(2) shown in Fig. 4, in terms of stratigraphy and layer thickness). In all three cases, the layered sequences are discretized into grids for use with the TOUGH2 reservoir simulator. For purposes of the feasibility study presented here, all three cases examine a two-dimensional north-south oriented simulation domain consistent with the regional structural trend of extension fractures in this portion of the San Juan Basin (Lorenz and Cooper, 2003) and thus the trend of highest hydraulic conductivity.

\subsubsection{Hydrogeological models}

In assessing hydrogeologic properties of the three sites (two Morrison, one Fruitland) for the purposes of modeling injection and storage, hydrostratigraphic units are defined and permeabilities for each were taken from published calibrated groundwater models. We make no additional inferences as to grid-scale heterogeneity (which is largely unknown for the injection lithologies of interest here) as per its influence on plume migration, but follow the example made by groundwater models for the regions in assuming constant properties per lithologic unit. For the Morrison cases the units of Thomas (1989) are used; while for the Fruitland

\begin{tabular}{|l|l|}
\hline Mancos Formation Dakota Formation \\
\hline Brushy Basin Member
\end{tabular}

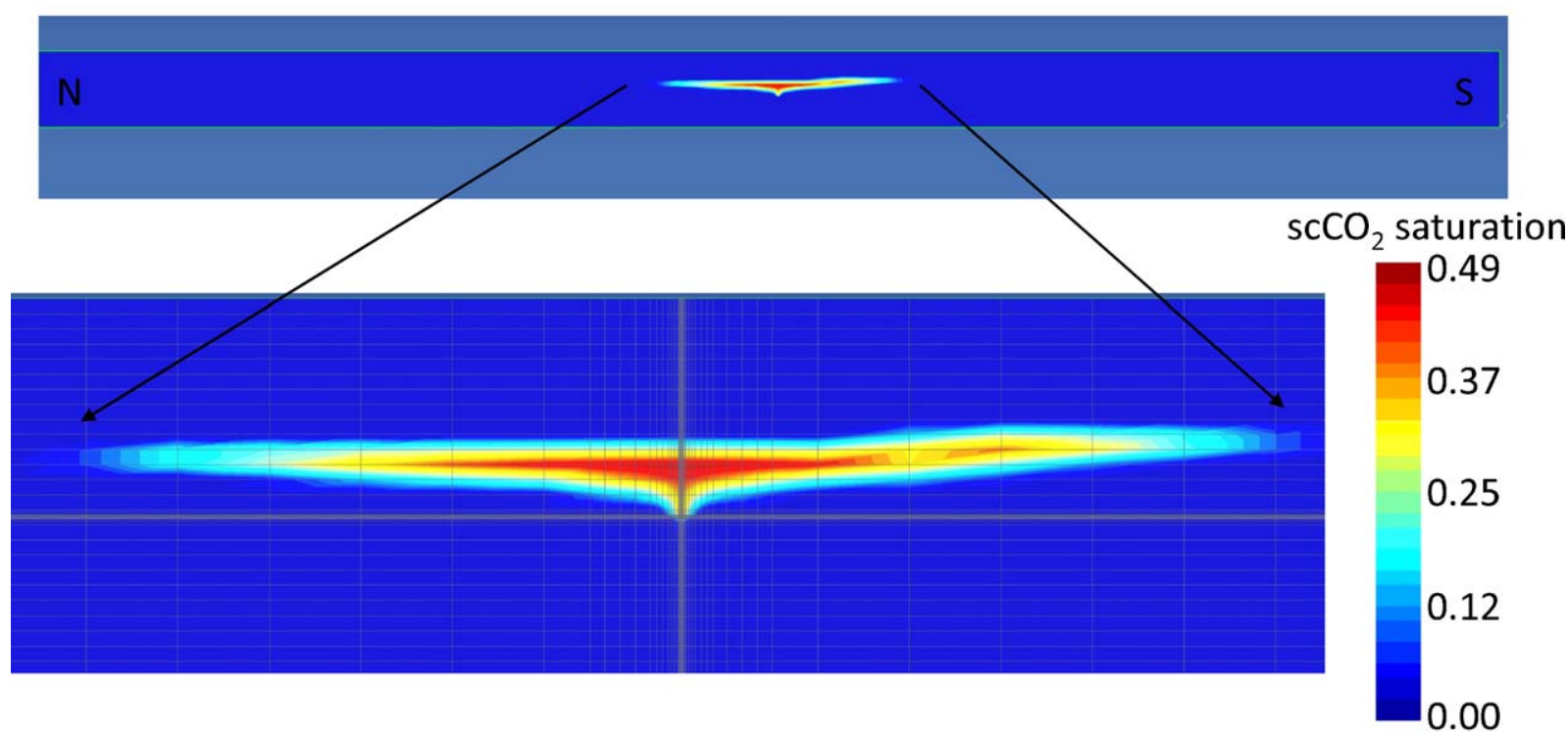

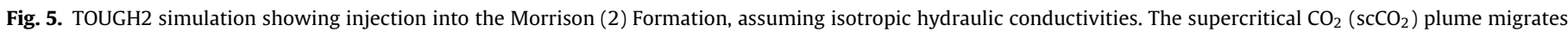
upward and against the Brushy Basin caprock after 30 years of injection. Horizontal axis is $12 \mathrm{~km}$, vertical axis is $1 \mathrm{~km}$. 
Table 1

Absolute permeabilities used for TOUGH2 modeling.

\begin{tabular}{lll}
\hline \multirow{2}{*}{ Hydro-stratigraphic unit } & \multicolumn{2}{l}{ Permeability $\left(\mathrm{m}^{2}\right)^{\mathrm{a}}$} \\
\cline { 2 - 3 } & Horizontal & Vertical \\
\hline Confining unit $^{\mathrm{b}}$ & $7.5 \mathrm{E}-16$ & $7.5 \mathrm{E}-20$ \\
Dakota Formation $^{\mathrm{c}}$ & $3.3 \mathrm{E}-13$ & $2.9 \mathrm{E}-17$ \\
Brushy Basin confining unit $^{\mathrm{c}}$ & $7.5 \mathrm{E}-15$ & $7.1 \mathrm{E}-18$ \\
Lower Morrison Formation $^{\mathrm{c}}$ & $4.1 \mathrm{E}-13$ & $2.9 \mathrm{E}-17$ \\
Wanaka confining unit $^{\mathrm{c}, \mathrm{d}}$ & $7.5 \mathrm{E}-15$ & $3.1 \mathrm{E}-17$ \\
Ojo Alamo Formation $^{\mathrm{e}, \mathrm{f}}$ & $2.5 \mathrm{E}-13$ & $5.1 \mathrm{E}-15$ \\
Kirtland confining unit $^{\mathrm{d}, \mathrm{f}}$ & $2.9 \mathrm{E}-18$ & $8.2 \mathrm{E}-20$ \\
Fruitland Formation $^{\mathrm{g}}$ & $5.8 \mathrm{E}-15$ & $5.8 \mathrm{E}-17$ \\
Pictured Cliffs Formation $^{\mathrm{h}}$ & $2.0 \mathrm{E}-15$ & $2.0 \mathrm{E}-17$ \\
Lewis Formation confining unit $^{\mathrm{i}}$ & $7.5 \mathrm{E}-16$ & $7.5 \mathrm{E}-20$ \\
\hline
\end{tabular}

a Assumes temperature of $30^{\circ} \mathrm{C}$ and brine density of $1100 \mathrm{~kg} / \mathrm{m}^{3}$.

b Frenzel (1983).

c Thomas (1989).

d Kernodle (1996).

e Thorn et al. (1990)

f Values of $K_{\mathrm{z}}$ from Heath (2010).

g Stone et al. (1983)

h Dam et al. (1990b)

i Values taken to be equivalent to those for Mancos shale.

case the analysis used hydrostratigraphy proposed by Kernodle (1996), Kernodle et al. (1989) and Frenzel and Lyford (1982). These are shown in the right-hand columns of Table 1 for both cases. Permeability values listed in Table 1 and used in the reservoir simulations were determined by the cited authors by calibrating groundwater models against available well and recharge data. Hydrostratigraphic units for the Morrison cases include the lower Jurassic Wanakah confining layer, members of the Jurassic Morrison Formation and injection horizon (Recapture and Westwater Canyon members), the Jurassic Brushy Basin confining unit (upper member of the Morrison Formation), the overlying Cretaceous Dakota Formation, and the Cretaceous lower Mancos confining unit (also known regionally as the Niobrara Group). Units for the Fruitland site (all Cretaceous) include the Lewis Formation confining unit, the Pictured Cliffs Formation, the Fruitland Formation (and injection horizon), the overlying Kirtland Formation confining unit, and the Ojo Alamo Formation. Lithologically, the injection and storage horizons are interbedded sands, muds, and shales, while the confining units are mostly mudstones.

\subsubsection{Injection and storage of $\mathrm{CO}_{2}$}

To model $\mathrm{CO}_{2}$ injection, migration, and phase partitioning with the TOUGH2 reservoir simulator, we require parameters for the multiphase flow properties, porosities, and densities for the hydrogeologic layers, most of which are largely unknown. We used a porosity of $13 \%$ and $15 \%$ for the Morrison Formation and Fruitland Formation injection horizons based on best estimates from the literature (Dam et al., 1990a; Kernodle et al., 1990); other parameters to describe multiphase flow in clastic sands, mudstones and shales were taken from Pruess (2005). Grids constructed in all cases consist of a coarse horizontal $500 \mathrm{~m}$-spaced grid with a finer grid (progressively down to $1 \mathrm{~m}$ spacing) surrounding an injection well centered within the simulation domains. Vertical grid resolution was taken to be a coarse grid of 50-100 m depending on formation thickness and fining at caprock reservoir boundaries and near injection zones to $1 \mathrm{~m}$. Boundary conditions applied to the simulation domain include open lateral boundaries (this was done by including artificially large volumes for model cells adjoining side boundaries), a closed (no-flux) lower boundary, and a constant pressure applied to the upper boundary at a magnitude consistent with a $0.01 \mathrm{MPa} / \mathrm{m}$ hydrostatic gradient.

Examples of $\mathrm{CO}_{2}$ injection and storage are shown in the next three figures. Fig. 5 shows a 2 -D example of injection at modest rates of $0.1 \mathrm{~kg} / \mathrm{s}$ into a $1-\mathrm{m}$ thick (dimension into the page) horizon for the Morrison (2) case as is applicable to injection from a horizontal well. In this case, vertical permeabilities were assumed equal to horizontal permeabilites. This shows the classic 'gravity override' buoyancy driven plume migration up against the Brushy Basin caprock. Fig. 6 shows a case using anisotropic permeabilities; in this case, the large anisotropy yields a more 'pancake' shaped plume. This is likely a more realistic scenario, with large lateral plume migration given the layered nature (i.e., with finer and coarser layers) of these sandstone reservoirs. A small 'mound' of overpressure produced by the injection is evident in Fig. 6. Fig. 7 shows the effect of simultaneous water withdrawal from a well positioned $6 \mathrm{~km}$ away from the injection well on the induced overpressure. Even at this great distance, overpressure can be mitigated by water withdrawal and treatment for beneficial use prior to the arrival of the $\mathrm{CO}_{2}$ plume at the withdrawal well.

\subsubsection{Plume migration and mass conservation}

The spatio-temporal modeling of $\mathrm{CO}_{2}$ injection in the previous examples can be used to bound the extent of plume migration and to calculate the fate of $\mathrm{CO}_{2}$ on time scales relevant to power plant operation. Plume migration distances, correlating to breakthrough times in water production wells as in Fig. 7, can be determined from sets of numerical experiments discussed above by varying injection rates and measuring plume extent with time. To do so, the analysis uses pseudo-3-D model grids with 2-D radial extent, to model the effect of 3-D migration. As an example, Fig. 8 shows results of plume migration distances as a function of time (up to 100 years of migration) for the Morrison (2) case. At small injection rates, distances increase roughly linearly with time, but as injection rates increase, plumes increase approximately with square root of time in accord with analytical models (i.e., Bickle et al., 2007). A departure from the analytical models is evident from our simulation results due to anisotropy, dissolution of supercritical $\mathrm{CO}_{2}$ in surrounding brine (and downward migration of the brine solution due to increased density), and gas/brine migration into surrounding formations with contrasting geohydrologic properties. We find that the radius $(L)$ of an effective pancake-shaped $\mathrm{CO}_{2}$ plume increases as a power law

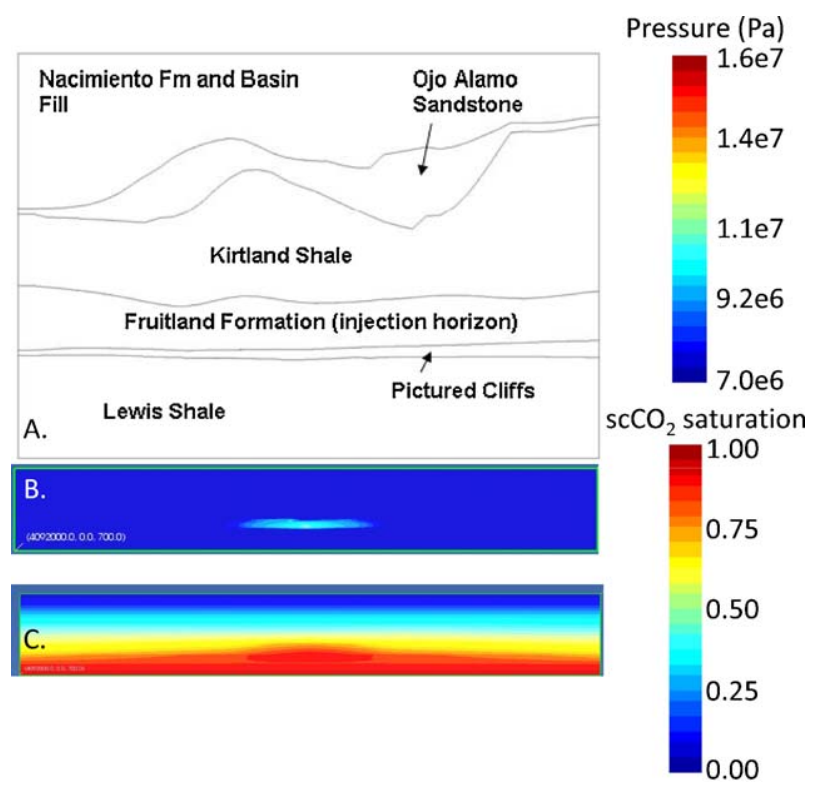

Fig. 6. TOUGH 2 model of injection within the Fruitland Formation assuming anisotropic permeabilities. (A) Cross section ( $10 \times$ vertical exaggeration) showing the Fruitland Formation injection horizon and overlying Kirtland Formation caprock. (B) Plume spreads laterally and up against Kirtland Formation caprock. (C) Small amount of overpressure attending injection after 30 years. 


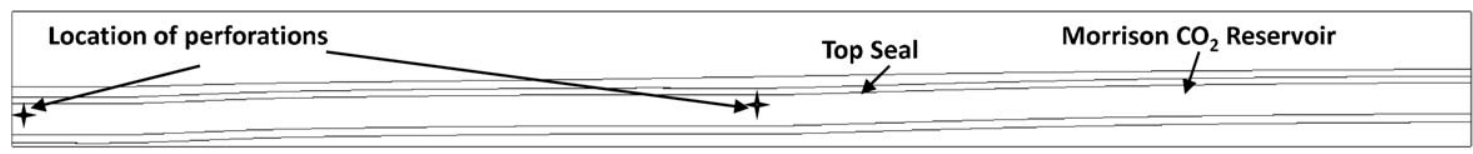

A.

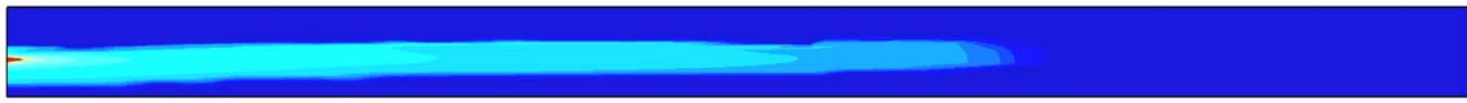

B.

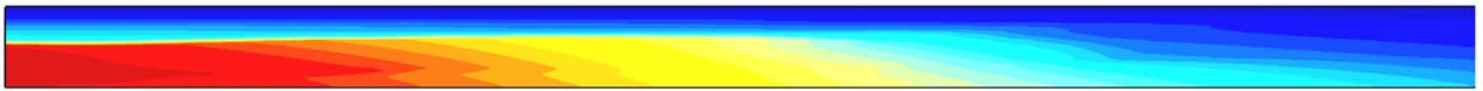

C.
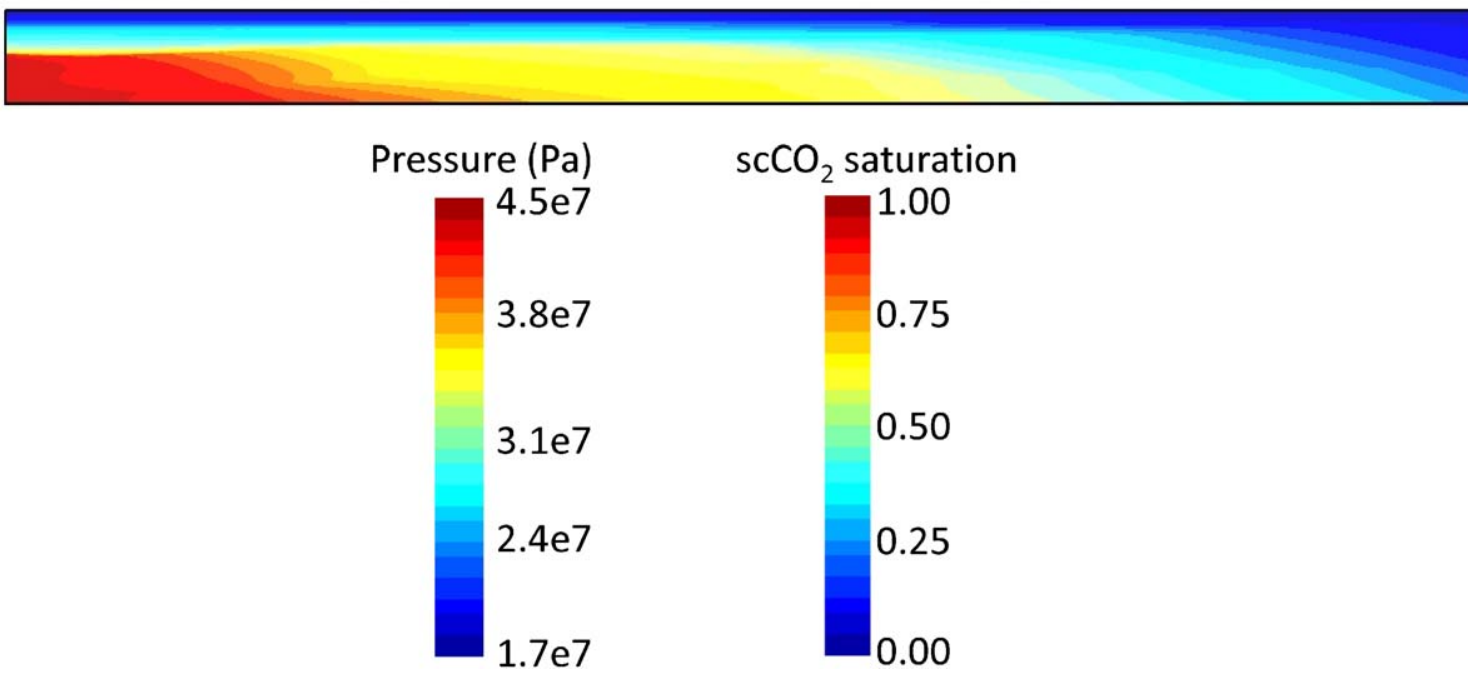

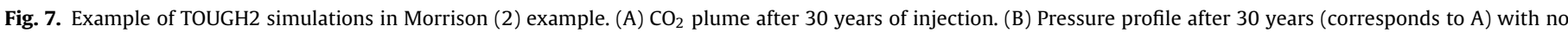
water withdrawal. (C) Pressure after equi-volume withdrawal of water from the formation, at the 'well' perforation zone in the middle of the simulation domain.

function of both injection rate $(I)$ and time $(t)$, such that

$L=16.35 I^{0.49} t^{0.40}$

for the Morrison cases and

$L=0.019 I^{0.34} t^{0.44}$

for the Fruitland site. Here $L$ is in $\mathrm{km}, I$ in tonnes/day, and time in years ( $R^{2}$ from linear regression analysis is 0.98 for both equations). The differences between the two models are attributable to differ-

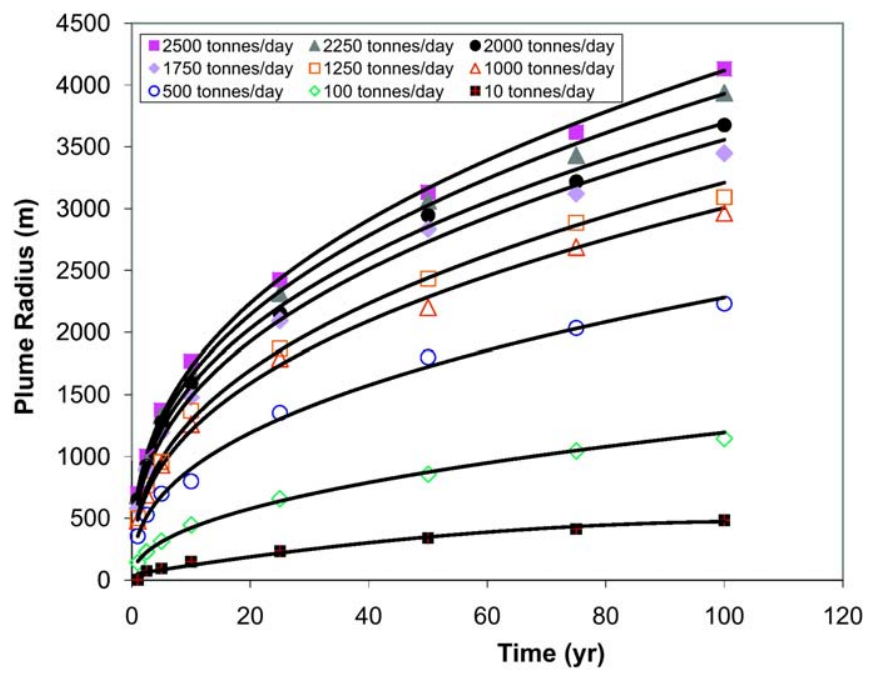

Fig. 8. Plume migration distance for the Morrison (2) example, plotted as a function of time and injection rate. Solid lines are fits to power-law expressions given in the text. ences in formation geometries, hydrogeologic properties, and those of surrounding lithologies including caprock. These expressions are used in the integrated assessment model developed for this study.

\subsection{Extracted water treatment}

Power plants may have both the demand for additional cooling water resources, and access to the potential financial means required to treat brackish water from geological saline formations. Population growth, drought, power generating technologies, carbon dioxide capture systems and water desalination technologies may all have very region-specific attributes. The confluence of these factors will determine the relative water stress due to water supply and demand imbalances (Tidwell et al., 2009).

Carbon dioxide capture technologies and their associated energy and water stream requirements pose substantial challenges for wide-spread adoption of these technologies (DOE/NETL, 2007). This analysis assumes that pulverized coal subcritical power plants use an amine absorber for the $\mathrm{CO}_{2}$ capture system which, under the current technology's readiness level, has a substantial water demand. Additionally, it is important to account for water chemistry in the design of the plant systems using this technology. There are site-specific limits on water treatment design based on the actual water quality, metallurgy of the piping system, materials of construction of the cooling tower itself, and regulations on the waste streams (liquid and solid). Cooling towers that utilize surface waters and/or low TDS well waters can easily meet many of these requirements and operate efficiently. However, many alternative sources of water (brackish from saline water-bearing formations, produced water from hydrocarbon extraction operations, waste water from municipalities and other sources) will most likely have elevated levels of chloride and other problematic constituents such 
Table 2

Summary of predicted HERO ${ }^{\mathrm{TM}}$ product water chemistry.

\begin{tabular}{|c|c|c|c|c|c|c|}
\hline \multirow[b]{2}{*}{ (ppm) } & \multicolumn{2}{|c|}{ Fruitland } & \multicolumn{2}{|c|}{ Morrison (1) } & \multicolumn{2}{|c|}{ Morrison (2) } \\
\hline & Initial & Product & Initial & Product & Initial & Product \\
\hline $\mathrm{Na}$ & 4100 & 74 & 1500 & 28 & 5400 & 99 \\
\hline $\mathrm{Ca}$ & 44 & $\mathrm{n} / \mathrm{a}$ & 310 & $\mathrm{n} / \mathrm{a}$ & 290 & $\mathrm{n} / \mathrm{a}$ \\
\hline $\mathrm{Mg}$ & 27 & $\mathrm{n} / \mathrm{a}$ & 49 & $\mathrm{n} / \mathrm{a}$ & 34 & $\mathrm{n} / \mathrm{a}$ \\
\hline $\mathrm{HCO}_{3}$ & 8000 & 6.0 & 270 & 0.20 & 880 & 0.70 \\
\hline $\mathrm{Cl}$ & 1500 & 45 & 58 & 1.8 & 2500 & 78 \\
\hline $\mathrm{SO}_{4}$ & 5.6 & 0.09 & 3800 & 64 & 7900 & 130 \\
\hline TDS & 14,000 & 260 & 6000 & 110 & 17,000 & 330 \\
\hline
\end{tabular}

as organic constituents, calcium, and silica. Elevated levels of chloride can lead to corrosion; elevated calcium, magnesium, and/or silica can lead to scale formation and increased energy consumption by the condensers. Higher TDS waters would require different and likely more expensive operational and maintenance costs, but they offer a potential supplemental source of cooling waters.

The water treatment for cooling water assumptions and calculations used herein are based on Zammit and DiFilippo (2004), the USBR (2003) desalination cost estimations, and insight from several additional studies (Klausner et al., 2004, 2005; McCabe et al., 1993; Miller, 2003). Zammit and DiFilippo (2004) present reverse osmosis treatment effectiveness for conventional reverse osmosis (CRO), High Efficiency Reverse Osmosis (HERO $\left.{ }^{\mathrm{TM}}\right)$, and other techniques to desalinate a brackish water with a TDS of approximately $12,000 \mathrm{ppm}$. The pre-treatment and $\mathrm{HERO}^{\mathrm{TM}}$ removal efficiencies for each element were calculated and used to predict the final product water for each of the waters evaluated in this study. While the $\mathrm{HERO}^{\mathrm{TM}}$ system was the technology selected for this analysis, others such as thermal desalination may be viable for higher ranges of salinity. This paper provides the methodology by which the technologies could be evaluated. Table 2 summarizes the initial feed water and the predicted product water chemistry.

Several desalination options were studied using a spreadsheet analysis to then become a central component of the integrated assessment. These options all utilized HERO ${ }^{\mathrm{TM}}$ (high efficiency reverse osmosis) for desalination and varied in the mode of waste water disposal. Although a HERO ${ }^{\mathrm{TM}}$ system may not be required (the waters may not have the high fouling constituents present), the cost estimations should be conservative. For additional clarity, Fig. 9 presents a schematic for the water treatment options used within the integrated assessment for the representative SJGS example.

Future work may compare other increased efficiency reverse osmosis systems, as well as other means of desalination. The water treatment cost estimate for a single formation (Morrison (2)) is summarized in Table 3. These options and assumptions are used in the integrated assessment model's calculations. The assumptions included in this model for HERO ${ }^{\mathrm{TM}}$ and brine concentrator capital and operational costs are based on the analysis developed in Zammit and DiFilippo (2004), which was based on specific water chemistry information. Therefore, analyzing formations with different water chemistries, and specifically salinity levels, will likely affect the capital and operational costs.

An analysis was also developed for the additional saline formation cases discussed in Section 4, and it is worth comparing the costs for each waste disposal option. These are summarized in Table 4, and largely vary due to differences in the base cost of electricity, cost to capture $\mathrm{CO}_{2}$, water chemistry, formation depth and distance from the power plant. Thus the Morrison (2) example bears the largest treatment costs. The least costly option is to store $\mathrm{CO}_{2}$ and extract water from the Morrison (1) example.

For additional comparison purposes, a recent study by MIT (2009) cites the base and retrofit costs of an old pulver- ized coal power generating station (such as the one presented here) as approximately 3.68 cents/kWh for the base cost and, 9.79-10.24 cents/kWh (2008 \$US) for the base cost plus $90 \% \mathrm{CO}_{2}$ capture for various technologies. The National Energy Technology Laboratory also cites similar costs for a puliverized coal plant with a base cost of approximately 3.38 and with $90 \%$ capture of $\mathrm{CO}_{2}$ of 7.79 cents/kWh (2007 \$US) (NETL, 2009). The base and $\mathrm{CO}_{2}$ capture costs presented in these two studies are in line with those underlying the results in Table 4 given the site-specific variables and uncertainties of power generating stations that will affect the cost to capture $\mathrm{CO}_{2}$ (e.g., coal type, Flue Gas Desulfurization system, physical layout of the power station).

\subsection{Integrated assessment model}

\subsubsection{Model design}

The goal of the integrated assessment model is to illustrate engineering and economic constraints associated with a suite of technologies applied to an existing power plant for both $\mathrm{CO}_{2}$ storage and beneficial use of treated water from a saline formation. The integrated assessment model builds on the geotechnical modeling and water treatment analyses developed in Sections 4.1 through 4.4.

The integrated assessment model incorporates the stocks and flows associated with the power plant's metrics including electricity production, flow of $\mathrm{CO}_{2}$, water resource needs, and it also identifies costs associated with the system's components. This model allows interested parties to perform 'what if' scenario analyses in real time for the interested scenario development user. For example, the model can address questions such as, 'What if the level of $\mathrm{CO}_{2}$ capture increases from $50 \%$ to $90 \%$ ? What will the electricity costs look like due to this change?' Similar scenario questions can be developed for different power plant configurations, geological formations used for $\mathrm{CO}_{2}$ storage, and brackish water treatment technologies.

The analysis applies the integrated assessment model to the SJGS/Morrison Formation example. The analysis evaluates $\mathrm{CO}_{2}$ storage into a saline formation along with a water extraction and treatment system to exploit the potential extracted brackish water to help meet a portion of the power plant's cooling needs.

\subsubsection{Base case parameters and costs}

The key metrics of interest provided by the integrated assessment model are the input variables for the SJGS, the representative formation characteristics (e.g., size, depth), as well as potential longevity of the formation to store $\mathrm{CO}_{2}$ and the amount of water extracted from the formation for beneficial use. Engineering variables in the integrated assessment model include the amount of $\mathrm{CO}_{2}$ generated by the plant per year, the percent of $\mathrm{CO}_{2}$ captured, pipe flow limitations, and the distance from the plant to injection wells. Economic variables include the capital and variable costs per well, discount rate, pipeline lifetime, and operations and maintenance costs. The costs associated with the $\mathrm{CO}_{2}$ capture system's components are based on work developed by NETL (2006/2007). The SJGS generates $\sim 13 \mathrm{M}$ tonne/yr of $\mathrm{CO}_{2}$ with an estimated water demand of $6.90 \mathrm{ft}^{3}$ per boiler (EPA, 2007). The analysis scenarios assume there can be a distance of $6-100 \mathrm{~km}$ from the injection well to the extraction well.

Morrison Formation storage volume and lifetime is linked to the $\mathrm{CO}_{2}$ plume extent, and its proximity to water extraction wells. The plume radius is dependent on time and injection rate as per Eq. (1), and the injection volume is assumed to be the volume of the cylinder given by the formation height and plume radius. The lifetime of storage is determined by the distance from the injection well to the first extraction well. When the plume radius equals this distance, storage is assumed to stop. A radius of $10 \mathrm{~km}$ yields a storage volume of $1069 \mathrm{M}$ tonnes, and a sink longevity of 162 years. 


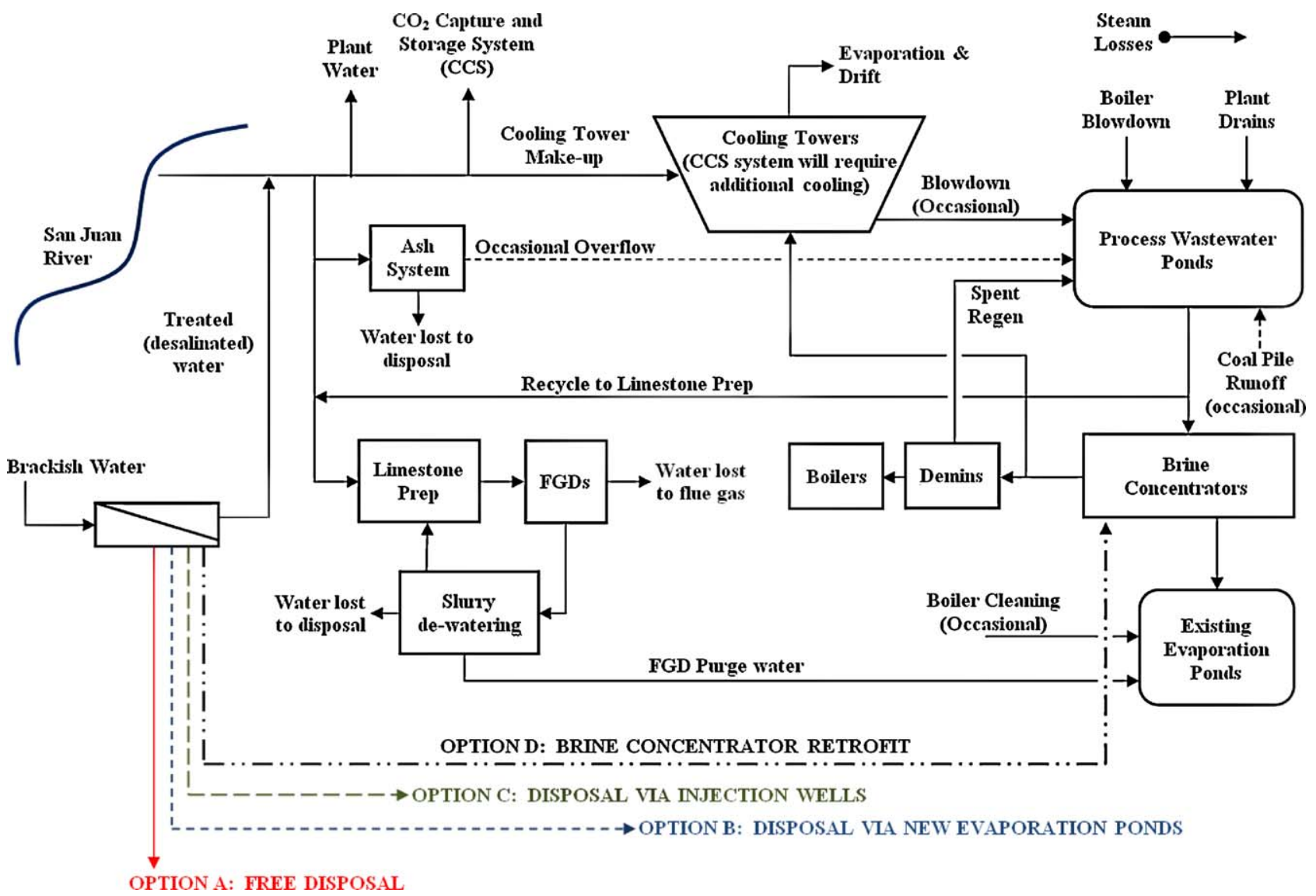

Fig. 9. Schematic of the water treatment options within the representative pulverized coal power generating station. Adapted from Zammit and DiFilippo (2004).

Capturing and storing $\mathrm{CO}_{2}$ within a saline bearing formation presents an opportunity to use the potentially displaced saline waters. Using the $\mathrm{CO}_{2}$ density displacement information outlined in Clark (1966) and Benthan and Kirby (2005), this modeling framework assumes under the base case scenario that (assuming hydrostatic pressure), every gram of $\mathrm{CO}_{2}$ injected underground displaces approximately $1.52 \mathrm{~cm}^{3}$ of saline water. While pressures involved with this base case lie within the supercritical range of the $\mathrm{CO}_{2}$ density-vapor curve analysis, the integrated assessment model allows for alternative potential densities of $\mathrm{CO}_{2}$ based on attributes of the formation under consideration. The initial depth for the Morrison (1) Formation is $4725 \mathrm{ft}$. This translates into an approximation where 400 gallons $(\sim 1500 \mathrm{~L})$ of saline water may be displaced for every tonne of $\mathrm{CO}_{2}$ stored under these representative conditions, and a total of 1.4 million gallons per day (MGD) of potential treated water. This represents $6 \%$ of the SJGS annual plant demand for water, and means that approximately 162 years of water for the SJGS resides in the Morrison.

Together with the base costs for water treatment given in Table 3 of $\$ 9.14$ per 1000 gallons of treated water, and the base cost for SJGS electricity of 5 cents $/ \mathrm{kWh}$, the total electricity costs for the Morrison (2) base case storage and HERO ${ }^{\mathrm{TM}}$ water treatment scenario increases the cost to approximately $9-12$ cents $/ \mathrm{kWh}$. Additional parameters and costs for the projected base case are summarized in Tables 4 and 5 .

\section{Discussion}

\subsection{Base case energy, water and net $\mathrm{CO}_{2}$ emissions}

Table 6 compares initial energy, water requirements, net $\mathrm{CO}_{2}$ emissions, and costs associated for the base SJGS power plant, base

Table 3

Summary of water treatment costs (2009 \$US).

\begin{tabular}{|c|c|c|c|c|}
\hline & Options $A^{a}$ & Option $\mathrm{B}^{\mathrm{b}}$ & Option $\mathrm{C}^{\mathrm{c}}$ & Option $\mathrm{D}^{\mathrm{d}}$ \\
\hline Annual O\&M & $\$ 2,458,798$ & $\$ 2,702,455$ & $\$ 2,524,172$ & $\$ 3,111,992$ \\
\hline Electricity Cost & $\$ 2.72 / 1000$ gallons & $\$ 2.72 / 1000$ gallons & $\$ 2.72 / 1000$ gallons & $\$ 3.87 / 1000$ gallons \\
\hline Total capital cost & $\$ 16,212,165$ & $\$ 32,455,934$ & $\$ 20,360,824$ & $\$ 19,594,244$ \\
\hline$\$ / 1000$ gallons $^{\mathrm{e}}$ & $\$ 7.34 / 1000$ gallons & $\$ 10.35 / 1000$ gallons & $\$ 8.11 \$ / 1000$ gallons & $\$ 9.14 / 1000$ gallons \\
\hline
\end{tabular}

a Desalination and gathering - equipment only (Brackish Water Reverse Osmosis (BWRO)); no concentrate disposal.

b Desalination and gathering - equipment only (BWRO); 59.5 acre evaporation ponds for concentrate disposal.

c Desalination and gathering - equipment only (BWRO); $3000 \mathrm{ft}$ injection pipeline, surface piping and well for concentrate disposal.

${ }^{d}$ Desalination and gathering - equipment - HERO ${ }^{\mathrm{TM}}+$ Brine Concentrator (BC) retrofit. Zammit and DiFilippo (2004), based on higher TDS.

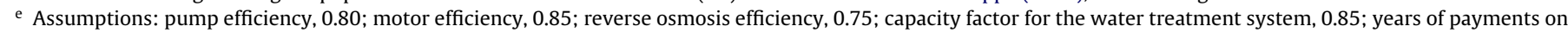

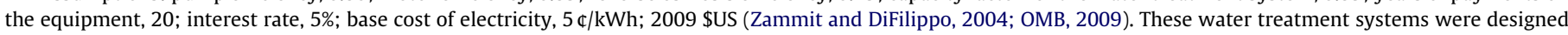
based on the size of the plant chosen for a retrofit case and the Morrison (2) 'Deep' scenario. 
Table 4

Water treatment costs for three saline formation examples, by water treatment option.

\begin{tabular}{|c|c|c|c|c|}
\hline Formation & $\begin{array}{l}\text { Option A BWRO (\$/1000 gallons, } \\
\left.(\mathbb{C} / \mathrm{kWh})^{\mathrm{a}, \mathrm{b}, \mathrm{c}, \mathrm{d}}\right)\end{array}$ & $\begin{array}{l}\text { Option B } \\
\text { BWRO-evaporation ponds }\end{array}$ & $\begin{array}{l}\text { Option C } \\
\text { BWRO-injection well }\end{array}$ & $\begin{array}{l}\text { Option D } \\
\text { HERO }^{\mathrm{TM}}+\mathrm{BC} \text { retrofit }\end{array}$ \\
\hline \multirow[t]{4}{*}{ Morrison (1) } & $6.26(8.91)^{\mathrm{a}}$ & $9.28(8.92)$ & $7.04(8.91)$ & $8.06(8.92)$ \\
\hline & $6.26(10.08)^{b}$ & $9.28(10.09)$ & $7.04(10.08)$ & $8.06(10.08)$ \\
\hline & $6.22(12.41)^{c}$ & $9.28(12.43)$ & $6.94(12.42)$ & $7.97(12.42)$ \\
\hline & $7.38(11.92)^{\mathrm{d}}$ & $10.40(11.93)$ & $8.16(11.92)$ & $9.88(11.93)$ \\
\hline \multirow[t]{4}{*}{ Morrison (2) } & $7.34(8.92)$ & $10.35(8.93)$ & $8.11(8.92)$ & $9.14(8.92)$ \\
\hline & $7.34(10.08)$ & $10.35(10.09)$ & $8.11(10.08)$ & $9.14(10.09)$ \\
\hline & $7.30(12.42)$ & $10.35(12.43)$ & $8.02(12.42)$ & $9.05(12.43)$ \\
\hline & $8.97(11.92)$ & $11.98(11.93)$ & $9.75(11.93)$ & $11.46(11.93)$ \\
\hline \multirow[t]{4}{*}{ Fruitland } & $6.48(8.91)$ & $9.50(8.92)$ & $7.26(8.91)$ & $8.28(8.92)$ \\
\hline & $6.48(10.08)$ & $9.50(10.09)$ & $7.26(10.08)$ & $8.28(10.08)$ \\
\hline & $6.38(12.41)$ & $9.43(12.43)$ & $7.10(12.42)$ & $8.13(12.42)$ \\
\hline & $7.40(11.92)$ & $10.42(11.93)$ & $8.18(11.92)$ & 9.90 (11.93) \\
\hline
\end{tabular}

Assumptions: $50 \% \mathrm{CO}_{2}$ capture at $\sim \$ 72 /$ tonne $\mathrm{CO}_{2}, 2009$ \$US.

a $5 \mathrm{c} / \mathrm{kWh}$ levelized cost of electricity (Zammit and DiFilippo, 2004; OMB, 2009).

b $5 \mathrm{c} / \mathrm{kWh}, 30 \%$ increase in $\mathrm{CO}_{2}$ capture cost above base case.

c $5 \mathrm{c} / \mathrm{kWh}, 90 \% \mathrm{CO}_{2}$ capture.

d $8 \mathbb{c} / \mathrm{kWh}$ base plant levelized cost of electricity (NETL, 2009), where: total system $\mathbb{c} / \mathrm{kWh}=$ base plant levelized cost of electricity (LCOE $\mathrm{Lase}_{\text {blant }}$ ) $+\mathbb{c} / \mathrm{kWh}$ for $\mathrm{CO}_{2}$ capture

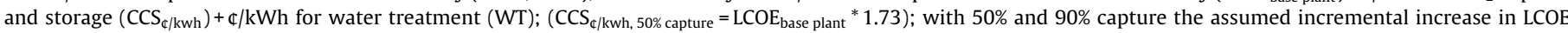

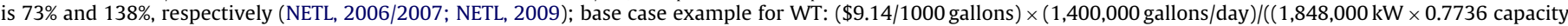
factor $\times 24 \mathrm{~h} /$ day $)$ ) $=0.04 \mathrm{c} / \mathrm{kWh}$ for water treatment; Kobos et al. (2010) contains additional detail on the modeling assumptions.)

Table 5

Projected base case $\mathrm{CO}_{2}$ capture, storage, and water treatment costs ${ }^{\mathrm{a}}$.

\begin{tabular}{|c|c|c|c|}
\hline Input variable & Base case value & Result parameter & Result value \\
\hline Power plant emissions $\left(\mathrm{CO}_{2}\right)$ & $13,165,665$ tonne/yr & $\mathrm{CO}_{2}$ sink longevity & 162 years \\
\hline$\% \mathrm{CO}_{2}$ captured & $50 \%$ & Potential treated water & 1.4 MGD \\
\hline Formation depth & $6359 \mathrm{ft}$ & $\%$ of annual plant demand met & $6 \%$ \\
\hline Formation size & $1069 \mathrm{mmt}$ & Years' worth of $\mathrm{H}_{2} \mathrm{O}$ in formation for plant & 162 years \\
\hline \multirow{4}{*}{ Power plant water demand } & $6.90 \mathrm{ft}^{3} / \mathrm{s} /$ boiler & Plume migration distance & $3164 \mathrm{~m}$ (40 years) \\
\hline & & Electricity cost & $5 \mathrm{c} / \mathrm{kWh}$ \\
\hline & & Water treatment cost & $\$ 9.14 / 1000$ gallons $\mathrm{H}_{2} \mathrm{O}$ \\
\hline & & Total electricity cost & 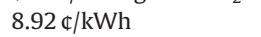 \\
\hline
\end{tabular}

a San Juan Generating Station tonnes $\mathrm{CO}_{2} / \mathrm{yr}, 50 \%$ capture, Morrison (2) deep formation, $8 \mathrm{CO}_{2}$ storage wells, one $\mathrm{H}_{2} \mathrm{O}$ recovery well, $\mathrm{HERO} \mathrm{TM}^{\mathrm{TM}}$ water treatment system, 2009 \$US, plume migration according to $L=16.35 I^{0.49} t^{0.40}$ where $L$ is the plume radius (km), $I$ is injection rate (tonnes/day) and $t$ is time in years.

Table 6

Base case energy, water and net $\mathrm{CO}_{2}$ emissions ${ }^{\mathrm{a}}$.

\begin{tabular}{|c|c|c|c|c|c|}
\hline Parameter & Energy (MW) & $\mathrm{H}_{2} \mathrm{O}$ requirement (MGD) & New, treated $\mathrm{H}_{2} \mathrm{O}$ (MGD) & Net $\mathrm{CO}_{2}$ (tonne/yr) & Economics $(\mathbb{c} / \mathrm{kWh})^{\mathrm{a}}$ \\
\hline Base power plant & 1848 & 17.84 & $\mathrm{n} / \mathrm{a}$ & $13,165,665$ & 5 \\
\hline Base $+\mathrm{CO}_{2}$ capture and storage and wells (CCS) & 2209 & 24.54 & $\mathrm{n} / \mathrm{a}$ & $9,152,267$ & 8.88 \\
\hline Base + CCS + water treatment & 2210 & 24.66 & 1.4 & $9,164,202$ & 8.92 \\
\hline
\end{tabular}

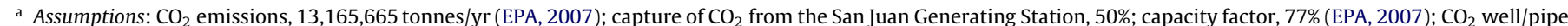

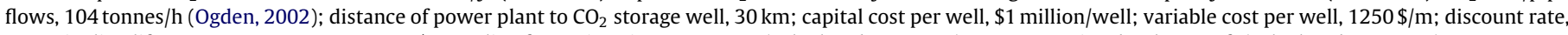
10\%; pipeline life, 30 years; O\&M, 0.04; 2009 \$US; saline formation size, $1069 \mathrm{mmt}$ (calculated, TOUGH2); representative depth, $6359 \mathrm{ft}$ (calculated, TOUGH2).

SJGS plus CCS, and base SJGS plus CCS plus extracted water treatment and beneficial use as cooling water. Adding CCS will increase energy needs by about $20 \%$, along with an increase in water needs by about $43 \%$. This accomplishes a net $\mathrm{CO}_{2}$ reduction from an initial $13 \mathrm{M}$ tonnes/yr to about $9 \mathrm{M}$ tonnes/yr with costs increasing from 5 cents $/ \mathrm{kWh}$ to approximately 9 cents $/ \mathrm{kWh}$. Adding water treatment to this base scenario does not change energy demand substantially, marginally increases the net $\mathrm{CO}_{2}$ emissions from the CCS case and increases costs by less than 1 cent $/ \mathrm{kWh}$. To summarize, retrofitting an existing plant like the SJGS may increase the energy penalty by approximately 360 megawatts (MW), or a $20 \%$ energy penalty under the initial assumptions. Additionally, this will decrease the plant's overall $\mathrm{CO}_{2}$ emissions profile by $43 \%$ (this includes the $50 \%$ capture, plus the associated required parasitic power plant's emissions for the CCS system).

\subsection{What about $\mathrm{CO}_{2}$ capture?}

Probably the largest uncertainty in the integrated assessment's analysis is the amount of $\mathrm{CO}_{2}$ that is able to be captured, and the resulting influence on this coupled-use system's economics. The trends plotted in Fig. 10 show that as the percent of $\mathrm{CO}_{2}$ captured increases, the potential to meet a portion of the power plant's water needs also increases. Similarly, the percent of annual water demands met for the representative power plant may also increase as volumes of $\mathrm{CO}_{2}$ stored in saline formations increase. Interestingly, there is only a slight decrease in water treatment costs (in $\$ / 1000$ gallons of water treated). Increasing the percent of $\mathrm{CO}_{2}$ captured from $50 \%$ to $90 \%$ leads to an increase in total electricity costs from approximately 9-12 cents/kWh.

It is important to examine the influence of the percent $\mathrm{CO}_{2}$ capture amount on the number of $\mathrm{CO}_{2}$ injection wells as it relates to performance and costs. During preliminary runs of the TOUGH2 reservoir modeling of the Morrison Formation, accepting $\mathrm{CO}_{2}$ assumes a representative one well scenario. The analysis assumes each well can inject up to 2500 tonnes of $\mathrm{CO}_{2}$ per day. This represents approximately $7 \%$ of the annual $\mathrm{CO}_{2}$ emissions profile for the SJGS. To capture and store $50 \%$ of the total annual $\mathrm{CO}_{2}$ emissions, approximately eight wells may be required. Thus, implementing this type of system with one initial $\mathrm{CO}_{2}$ injection well, the potential 


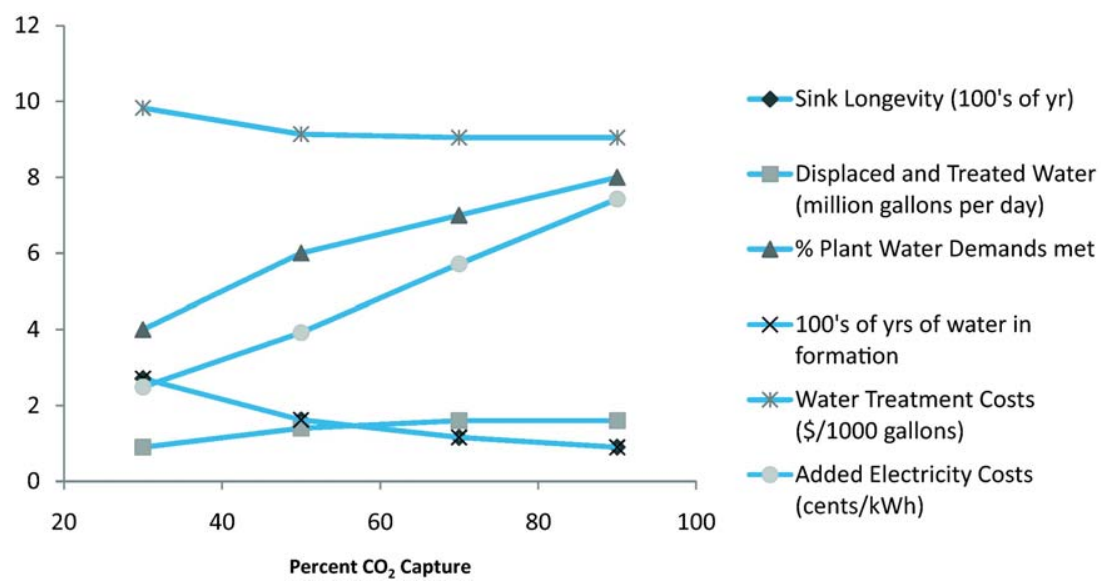

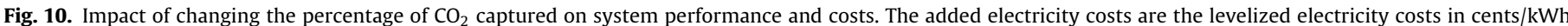
assuming $\mathrm{CO}_{2}$ capture, pipeline, $\mathrm{CO}_{2}$ injection wells, water extraction wells, and water treatment costs.

displaced water would meet approximately $1 \%$ of the plant's annual water demands when accounting for storing $6 \%$ of the plant's total $\mathrm{CO}_{2}$. As a result, the costs, flow rates and annual $\mathrm{CO}_{2}$ capacity and water supply could change dramatically depending on the geosystem characteristics, the engineering of the $\mathrm{CO}_{2}$ capture and storage system, and regulatory constraints associated with using a saline formation resource for these purposes.

\subsection{Future work}

The analytical team responsible for the work presented here continues to expand the modeling framework to include additional U.S. formations with the aim of offering a multi-formation assessment tool. The analysis is developing and expanding the scale and scope of the user model's input, and expanding the framework presented here into a national-scale assessment. With this information, users will be able to draw from existing saline formation databases such as NatCarb (coordinated by NETL), power plant databases such as eGRID (developed by the EPA), and build from geochemical and geomechanical studies of $\mathrm{CO}_{2}$ storage and develop additional custom, site specific scenarios. This will lay the groundwork as a first order assessment for potential pilot plant-scale studies and assessing the scale-up potential for these combined technologies in the face of water stress throughout the U.S.

\section{Conclusions}

An integrated assessment model was developed to quantify the potential economic feasibility for combined water extraction, treatment, and beneficial use with $\mathrm{CO}_{2}$ storage in the southwestern United States. This includes examining salinity levels of regional saline formations, evaluating water usage for select power plant profiles, and determining cost and systems management requirements. These efforts all contribute to a decision support analysis for potential future $\mathrm{CO}_{2}$ storage and extracted water use at the power plant level. Geochemical modeling of $\mathrm{CO}_{2}$ injection shows that little $\mathrm{CO}_{2}$ is stored in mineral form for engineering time scales up to centuries. Selective carbon dioxide injection does not modify water chemistry to the point of deleteriously affecting extracted water treatment options. Reservoir modeling of $\mathrm{CO}_{2}$ injection and migration in target saline formations suggests plume migration can be quantified by simple power-law expressions for use in the systems modeling, and shows how water extraction can be used to mitigate injection-induced overpressures. From amongst available water treatment options, the high efficiency reverse osmosis $\left(\mathrm{HERO}^{\mathrm{TM}}\right)$ system shows promise for economical desalination of the volumes of recovered water, with pore water chemistries characteristic of deep saline formations in the southwestern United States. For the base case using results from geochemical, reservoir engineering, and water treatment analyses, approximately $6 \%$ of power plant water needs can be met while capturing approximately $50 \%$ of $\mathrm{CO}_{2}$ emissions, and increasing levelized electricity costs by a factor of approximately 2 . This would suggest that a coupled use system similar to the one suggested here could be technically feasible for power plants similar to the SJGS, if the increased costs are viewed as economically acceptable to the regions served by the power plant.

\section{Acknowledgements}

The authors wish to thank Tom Feeley, Jared Ciferno and Lynn Brickett of the National Energy Technology Laboratory for initiating and funding this study. The authors also thank Geoffrey T. Klise for his assistance in developing the Geographic Information Systems maps and Jesse D. Roach for related analyses. Sandia National Laboratories is a multi-program laboratory managed and operated by Sandia Corporation, a wholly owned subsidiary of Lockheed Martin Corporation, for the U.S. Department of Energy's National Nuclear Security Administration under contract DE-AC04-94AL85000.

\section{References}

Allis, R.G., Chidsey, T.C., Morgan, C., Moore, J., White, S.P., 2003. $\mathrm{CO}_{2}$ sequestration potential beneath large power plants in the Colorado Plateau-southern Rocky Mountain region, USA. Proceedings 2nd Annual Conference on Carbon Sequestration, Alexandria VA, May 5-8, 2003 (Sponsored by the US DOE).

Benthan, M., Kirby, G., 2005. $\mathrm{CO}_{2}$ storage in saline aquifers. Oil and Gas Science and Technology, 60 (3), 559-567.

Bachu, S., Adams, J.J., 2003. Sequestration of $\mathrm{CO}_{2}$ in geological media in response to climate. change: capacity of deep saline aquifers to sequester $\mathrm{CO}_{2}$ in solution. Energy Conversion and Management 22, 3151-3175.

Bethke, C.M., 1998. The Geochemist's Workbench: A Users Guide to Rxn, Act2, Tact React, and Gtplog. University of Illinois, Hydrology Program.

Bickle, M., Chadwick, A., Huppert, H., Hallworth, M., Lyle, S., 2007. Modelling carbon dioxide accumulation at Sleipner: implications for underground carbon storage. Earth and Planetary Science Letters 255, 164-176.

Clark, S.P., Jr., 1966. Handbook of Physical Constants. Geological Society of America Memoir 97. Published by the Society, GSA Publishers, NY, 587 pp.

Dam, W.L., Kernodle, J.W., Levings, G.W., Craigg, S.D., 1990a. Hydrogeology of the Morrison Formation in the San Juan Structural Basin, New Mexico, Colorado, Arizona, and Utah. U.S. Geological Survey Hydrologic Investigations Atlas HA720-J.

Dam, W.L., Kernodle, J.W., Thorn, C.R., Levings, G.W., Craigg, S.D., 1990b. Hydrogeology of the Pictured Cliffs Sandstone in the San Juan Structural Basin, New Mexico, Colorado, Arizona, and Utah. U.S. Geological Survey Hydrologic Investigations Atlas HA-720-D.

Department of Energy/National Energy Technology Laboratory (DOE/NETL), 2007. Power Plant Water Usage and Loss Study, August 2005, revised May 2007. 
Energy, Minerals and Natural Resources Department (EMNRD), 2008. State of New Mexico Oil Conservation Division (OCD). http://ocdimage.emnrd.state. nm.us/imaging/WellFileCriteria.aspx.

Environmental Protection Agency (EPA), 2007. Emissions \& Generation Resource Integrated Database (eGRID). Version 1.0. http://www.epa.gov/ cleanenergy/energy-resources/egrid/index.html.

Environmental Protection Agency (EPA), 2008. EPA Proposes New Requirements for Geologic Sequestration of Carbon Dioxide, EPA 816-F-08-032, July.

Frenzel, P.F., Lyford, F.P., 1982. Estimates of vertical hydraulic conductivity and regional ground-water flow rates in rocks of Jurassic and Cretaceous age, San Juan Basin, New Mexico and Colorado. U.S. Geological Survey Water Resources Investigations Report 82-4015, 59 pp.

Frenzel, P., 1983. Simulated changes in ground-water levels related to proposed development of Federal coal leases, San Juan Basin, New Mexico. USGS Open File Report 83-949, 63 pp.

Grataloup, S., Bonijoly D., Etienne, B., Dreux, R., Garcia, D., Hasanov, V., Lescanne, M., Renoux, P., Thoraval, A., 2009. A site selection methodology for $\mathrm{CO}_{2}$ underground storage in deep saline aquifers: case of the Paris Basin, GHGT-9, 29292936.

Heath, J.E., 2010. Multi-Scale Petrography and Fluid Dynamics of Caprock Seals Associated with. Geologic $\mathrm{CO}_{2}$ Storage. Unpublished Ph.D. Dissertation, New Mexico Institute of Mining and Technology, Socorro, New Mexico.

Herzog, H.J., 2010. Scaling up carbon dioxide capture and storage: From megatons to gigatons, Energy Economics. doi:10.1016/j.eneco.2010.11.004.

Hovorka, S.D., Romero, M.L., Treviño, R.H. Warne, A.G., Ambrose, W.A., Knox, P.R., Tremblay, T.A., 2000. Technical summary: optimal geological environments for carbon dioxide disposal in brine-bearing formations (aquifers) in the United States: The University of Texas at Austin, Bureau of Economic Geology, final report prepared for U.S. Department of Energy, National Energy Technology Laboratory, under contract no. DE-AC26-98FT40417, 232 p. GCCC. Digital Publication Series \#00-01.

Kernodle, J.M., 1996. Hydrogeology and steady-state simulation of ground-water flow in the San Juan Basin, New Mexico, Colorado, Arizona, and Utah. U.S. Geological Survey Water Resources Investigations Report 95-4187, 117 pp.

Kernodle, J.M., Levings, G.W., Craigg, S.D., Dam, W.L., 1989. Hydrogeology of the Gallup Sandstone in the San Juan Structural Basin, New Mexico, Colorado, Arizona, and Utah. U.S. Geological Survey Hydrologic Investigations Atlas HA720-H.

Kernodle, J.M., Thorn, C.R., Levings, G.W., Craigg, S.D., Dam, W.L., 1990. Hydrogeology of the Kirtland Shale and Fruitland Formation in the San Juan Structural Basin, New Mexico, Colorado, Arizona, and Utah. U.S. Geological Survey Hydrologic Investigations Atlas HA-720-C.

Kharaka, Y.K., Cole, D.R., Hovorka, S.D., Gunter, W.D., Knauss, K.G., Freifeld, B.M., 2006. Gas-water-rock interactions in the Frio Formation following $\mathrm{CO}_{2}$ injection: implications for the storage of greenhouse gases in sedimentary basins. Geology July, 577-580.

Kharaka, Y.K., Thordsen, J.J., Hovorka, S.D., Nance, H.S., Cole, D.R., Phelps, T.J., Knauss, K.G., 2009. Potential environmental issues of $\mathrm{CO}_{2}$ storage in deep saline aquifers: geochemical results from the Frio-I Brine Pilot test, Texas, USA. Applied Geochemistry $24,1106-1112$

Klara, S.M., Srivastava, R.D., McIlvried, H.G., 2003. Integrated collaborative technology. development program for $\mathrm{CO}_{2}$ sequestration in geologic formations-United States Department of energy R\&D. Energy Conservation and Management 44, 2699-2712.

Klausner, J., Li, Y., Darwish, M., Renwei, M., 2004. Innovative diffusion driven desalination process. Journal of Energy Resources Technology 126, 219-225.

Klausner, J., Li, Y., Darwish, M., Renwei, M., 2005. Innovative fresh water production process for fossil fuel plants, 2005 Annual Report, NETL.

Kobos, P.H., Cappelle, M.A., Krumhansl, J.L., Dewers, T., Borns, D.J., Brady, P.V., McNemar, A., 2008. Using Saline Aquifers for Combined Power Plant Water Needs and Carbon Sequestration. 28th USAEE/IAEE North American Conference, New Orleans, LA, December 3-5, 2008.

Kobos, P.H., Krumhansl, J.L., Dewers, T.A., Cappelle, M.A., Heath, J.E., Dwyer, B.P., Borns, D.J., McNemar, A., 2010. Study of the Use of Saline Formations for Combined Thermoelectric Power Plant Water Needs and Carbon Sequestration at a Regional Scale: Phase II Report, SAND2010-8073P.

International Energy Agency Greenhouse Gas (IEAGHG) Research and Development Programme, 2009. A review of the international state of the art in risk assessment guidelines and proposed terminology for use in $\mathrm{CO}_{2}$ geological storage.

Litynski, J.T., Plasynski, S., Mcllvried, H.G., Mahoney, C., Srivastava, R.D., 2008 The United States Department of Energy's Regional Carbon Sequestration Partnerships Program Validation Phase. Environment International 34, 127-138.

Litynski, J., Plasynski, S., Spangler, L., Rinley, R., Steadman, E., Ball, D., Nemeth, K.J., McPherson, B., Myer, L., 2009. U. S. department of energy's regional carbon sequestration partnership program: overview. Energy Procedia 1, 3959-3967.

Lorenz, J., Cooper, S., 2003. Tectonic setting and characteristics of natural fractures in Mesaverde and Dakota reservoirs of the San Juan Basin. New Mexico Geology, $25,3-15$.
Lucier, A., Zoback, M., 2008. Assessing the economic feasibility of regional deep saline aquifer $\mathrm{CO} 2$ injection and storage: A geomechanics-based workflow applied to the Rose Run sandstone in Eastern Ohio, USA, International Journal of Greenhouse Gas Control 2 (2), 230-247.

Massachusetts Institute of Technology (MIT), 2009. Retrofitting of Coal-Fired Power Plants for $\mathrm{CO}_{2}$ Emissions Reductions, MIT Energy Initiative.

McCabe, W., Smith, J., Harriott, P., 1993. Unit Operations of Chemical Engineering, 5th edn. McGraw-Hill, Inc.

Medina, C., Rupp, J.A., Barnes, D.A., 2011. Effects of reduction in porosity and permeability.with depth on storage capacity and injectivity in deep saline aquifers: a case study from the Mount Simon Sandstone aquifer, International Journal of Greenhouse Gas Control, In Press.

Michael, K., Arnot, M., Cook, P., Ennis-King, J., Funnell, R., Kaldi, J., Kirste, D., Paterson, L., 2009. $\mathrm{CO}_{2}$ storage in saline aquifers I-current state of scientific knowledge. Energy Procedia 1, 3197-3204.

Miller, J., 2003. Review of Water Resources and Desalination Technologies. Sandia Labs, SAND2003-0800, Albuquerque, NM, USA.

National Carbon Sequestration Database and Geographic Information System (NatCarb), 2008. http://www.natcarb.org/.

National Energy Technology Laboratory, 2009. Assessment of Power Plants That Meet Proposed Greenhouse Gas Emission Performance Standards, November DOE/NETL 401/110509.

National Energy Technology Laboratory (NETL), National Energy Technology Laboratory (NETL), 2006/2007. Carbon dioxide capture from existing coal-fired power plants. DOE/NETL-401-110907 (Final Report, Original Issue Date, December 2006).

National Research Council (NRC), 2008. Desalination: A National Perspective. The National Academies Press, Washington, D.C., USA.

Nicot, J.P., 2008. Evaluation of large-scale $\mathrm{CO}_{2}$ storage on fresh-water sections of aquifers: An example from the Texas Gulf Coast Basin. International Journal of Greenhouse Gas Control 2, 582-593.

Office of Management and Budget (OMB), 2009. Gross Domestic Product and Deflators Used in the Historical Tables.

Ogden, J., 2002. Modeling Infrastructure for a Fossil Hydrogen Energy System with $\mathrm{CO}_{2}$ Sequestration, Sixth Greenhouse Gas Control Technologies Conference, Kyoto, Japan.

Pruess, K., Oldenburg, C., Moridis, G., 1999. TOUGH2 User's Guide, Version 2. Lawrence Berkeley National Laboratory, LBNL-43134, 198 pp.

Pruess, K., Xu, T.F., Apps, J., Garcia, J., March 2003. Numerical modeling of aquifer disposal of $\mathrm{CO}_{2}$. SPE Journal 8 (1), 49-60.

Pruess, K., 2005. ECO2N: A TOUGH2 fluid property module for mixtures of water $\mathrm{NaCl}$, and $\mathrm{CO}_{2}$. Lawrence Berkeley National Laboratory, LBNL-43134, 66 pp.

Stone, W., Mizell, N., 1978. Basis subsurface data compiled for hydrogeologic study of the San Juan Basin, northwest New Mexico. New Mexico Bureau of Mines and Mineral Resources, Open File Report 89, 74 pp.

Stone, W.J., Lyfrod, F.P., Frenzel, P.F., Mizell, N.H., Padgett, E.T., 1983. Hydrogeology and Water Resources of San Juan Basin, New Mexico: New Mexico Bureau of Mines and Mineral Resources Hydrologic Report 6, 70 pp.

Thorn, C.R., Levings, G.W., Craigg, S.D., Dam, W.L., Kernodle, J.M., 1990. Hydrogeology of the Ojo Alamo Sandstone in the San Juan Structural Basin, New Mexico, Colorado, Arizona, and Utah. U.S. Geological Survey Hydrologic Investigations Atlas HA-720-B.

Thomas, B., 1989. Simulation analysis of the ground-water system in Mesozoic rocks in the Four Corners Area, Utah, Colorado, Arizona, and New Mexico, USGS Water Resources Investigations Report 88-4086, 87 pp.

Tidwell, V.C., Kobos, P.H., Malczynski, L., Klise, G., Hart, W.E., Castillo, C., 2009. Decision Support for Integrated Water Energy Planning. SAND2009-6521 Report.

United States Bureau of Reclamation(USBR), 2003. Desalting Handbook for Planners, 3rd Edition.

United States Bureau of Reclamation (USBR) and Sandia National Laboratories (SNL), 2003. Desalination and Water Purification Technology Roadmap-A Report of the Executive Committee, Desalination and Water Purification Research and Development Program Report \#95.

White, S.P., Allis, R.G., Moore, J., Chidesy, T., Morgan, C., Gwynn, W., Adams, M., 2005 Simulation of reactive transport of injected $\mathrm{CO}_{2}$ on the Colorado Plateau, Utah, USA. Chemical Geology 217 (3-4), 387-405.

$\mathrm{Xu}$, T.F. Apps, J.A., Pruess, K., Feb. 4, 2003. Reactive geochemical transport simulation to study mineral trapping for $\mathrm{CO} 2$ disposal in deep arenaceous formations-art. no. 2071. Journal of Geophysical Research-Solid Earth 108 (B2), 2071-12071.

$\mathrm{Xu}, \mathrm{T}$.F., Apps, J.A., Pruess, K., 2004. Numerical simulation of $\mathrm{CO}_{2}$ disposal by minera trapping in deep aquifers. Applied Geochemistry 19 (6 (June)), 917-936.

Xu, T.F., Apps, J.A., Pruess, K., April 25, 2005. Mineral sequestration of carbon dioxide in a sandstone-shale system. Chemical Geology 217 (3-4), 295-318.

Xu, T.F., Apps, J.A., Pruess, K., Yamamoto, H., August 15, 2007. Numerical modeling of injection and mineral trapping of $\mathrm{CO}_{2}$ with $\mathrm{H}_{2} \mathrm{~S}$ and $\mathrm{SO}_{2}$ in a sandstone formation. Chemical Geology 242 (3-4), 319-346.

Zammit, K., DiFilippo, M., 2004. Use of Produced Water in Recirculating Cooling Systems at Power Generating Facilities, Treatment \& Disposal Analysis, SemiAnnual Technical Progress Report, April 12, 2004 to October 22, 2004. 